\title{
ECOLOGICAL-AND-HYGIENIC ESTIMATION OF DOMESTIC WASTE TRANSPORTATION IMPACT ON THE LANDFILL' AIR ENVIRONMENT
}

Malyshevska O., Harkavyi S., Myshchenko I., Pohorilyi M., Tokar I., Hrechukch L.

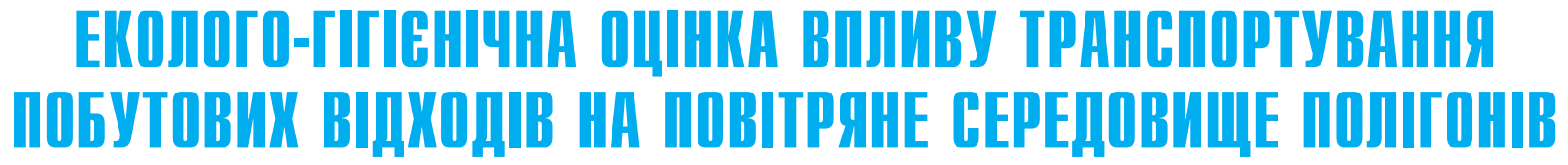

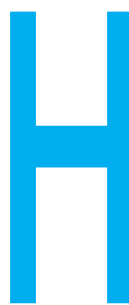

1МАЛИШЕВСЬКА О.С. , 2ГАРКАВИЙ С.С., 1 МИЩЕНКО І.А., 1ПОГОРІЛИЙ М.П.,

1ТОКАР І.Т., 1ГРЕЧУХ Л.С.

1 Івано-Франківський

національний медичний університет

2Національний медичний університет ім. О.О. Богомольця, м. Київ.

УДК 629.113:504.06:574.629

Ключові слова: комунальна гігієна, полімерні відходи, захоронення відходів, викиди автотранспорту. ині автомобільний транспорт перевозить 70-80\% усього вантажу у світі, при цьому обсяг забруднення атмосфери Землі автотранспортом становить 60-70\%. Відомо, що частка ефективної енергії двигунів внутрішнього згоряння - не більше $20 \%$ його об'єму, тоді як близько 80\% надходить в атмосферу і денатурує навколишнє природне середовище планети. Екологічний рівень розвитку автотранспорту різко відстає від вимог екологічних стандартів, але в Євросоюзі вже розпочаті дослідження за нормативами "зеленого" стандарту "Євро-7" [1, 2]

31 січня 2012 року автовиробники оснащують автомобілі двигунами, рівень викидів діоксиду вуглецю в яких не перевищує 130 г/км. У перспективі на 2020 рік прогнозується знизити цей показник до 95 г/км [3].

Відомо, що протягом доби автомобіль викидає до 1 кг вихлопних газів, хімічний склад яких небезпечний не тільки для здоров'я людини, але й тварин, рослин, ґрунту, води. Поєднання діоксиду азоту та вуглеводнів призводить до виникнення органічних сполук, які утворюЮть смог. Смог є причиною появи "кислотних дощів", які глобально змінюють усі ланки екологічної системи [4].

Окрім цього, додаткове навантаження на довкілля створюють оксигенатори бензину, кисневмісні сполуки, які покликані поліпшити згоряння пального, натомість мають високі міграційні властивості в об'єктах навколишнього середовища і чинять токсичний та потенційно онкогенний вплив [17]. Серед таких - метил третбутиловий ефір (2-метокси-2метилпропан, МТБЕ), що посідає перше місце. Обсяги світового щорічного споживання МТБЕ на 2016 рік становили 22,4 млн. т, а до 2021 року

\begin{abstract}
ЭКОЛОГО-ГИГИЕНИЧЕСКАЯ ОЦЕНКА ВЛИЯНИЯ ТРАНСПОРТИРОВКИ БЫТОВЫХ ОТХОДОВ НА ВОЗДУШНУЮ СРЕДУ ПОЛИГОНОВ

1 Малышевская О.С., 2Гаркавый С.С., 1 Мыщенко И.А., 1 Погорелый Н.П.,

1 Токар И.Т., 1 Гречух Л.С.

1 Ивано-Франковский национальный медицинский университет,

${ }^{2}$ Национальний медицинский университет им. А. А. Богомольца, г. Киев.
\end{abstract}

Цель - провести эколого-гигиеническую оценку процесса захоронения твердых бытовых отходов на полигонах

Материалы и методы исследования.

Проведен анализ технологических операций процесса захоронения бытовых отходов на примере КП "Полигон ТБО" в Ивано-Франковской области. Результаты были получены в процессе натурных инструментальных исследований специалистами с использованием оборудования ГУ "Ивано-Франковский областной лабораторный центр МЗ Украины" для НИР № $0117 \cup 004237$. Анализ запыленности воздуха проводили прибором "АФА-ВП-20"; определение концентрации химических веществ в воздухе - с помощью электроаспиратора "ЭА-1212", поглотителей Рихтера и Зайцева, фотоэлектроколориметра "КФК-2", газового хроматографа "Кристалл
2000 M". Расчеты проведены согласно "Методике расчета выбросов загрязняющих веществ и парниковых газов в атмосферу от транспортных средств".

Результаты и их обсуждение. Зафиксировано превышение уровня ПДК и ПДУ по всем изучавшимся физическим и химическим факторам. В частности, превышение уровней ПДК для канцерогенных, мутагенных и высокотоксичных веществ составляет для формальдегида до 1967 раз, для свинца - до 120000 раз, для бенз(а)пирена - до 793 раз.

Выводы и перспективы. Наибольший выброс в атмосферный воздух населенных пунктов оказывают процессы разгрузки и уплотнения отходов. Максимальное загрязнение наблюдается от наиболее длительного процесса захоронения - уплотнения. Основная причина превышения выбросов - физический износ автопарка, вывозящего ТБО на полигон.

Перспективным направлением в научных исследованиях является разработка и внедрение технологий, уменьшающих объем отходов, которые вывозят для захоронения, в частности наиболее тоннажной составляющей бытовых отходов полимеров.

Ключевые слова: коммунальная гигиена, полимерные отходы, захоронение отходов, выбросы автотранспорта.

() Малишевська О.С., Гаркавий С.С., Мищенко І.А., Погорілий М.П.,

Токар І.Т., Гречух Л.С. СТАТТЯ, 2018. 
(незважаючи на високі міграційні властивості хімічна сполука потрапляє у підземні води та забруднює їх) вказані обсяги зростуть до 26,5 млн. т $[17,18]$.

За допомогою автотранспорту вантажопідйомністю 5-10 т здійснюється процес вивезення та захоронення побутових відходів у спеціально відведені місця чи об'єкти. 2016 року захоронення склали 157,4 млн. т (на 5,1 млн. т більше, ніж у 2015 році), а для їх транспортування та утилізації було використано близько 1,8 млн. одиниць техніки [5].

Аналіз літературних даних та постановка проблеми. На основі аналізу робіт вітчизняних та світових науковців-онкологів встановлено, що полігони твердих побутових відходів мають значний канцерогенний вплив на здоров'я населення $[6,7]$. У роботах [8-14] встановлено зв'язок між чисельністю захворювань на рак і місцями накопичення звалищ твердих побутових відходів (ТПВ). Авторами отримано дані щодо захворювань на рак печінки, легень, лейкемії і саркоми м'яких тканин [6]. Дослідженнями встановлено, що ризик передчасних пологів та викиднів зростає від $2 \%$ до $6 \%$, вроджених аномалій внутрішніх органів - до 63\% у новонароджених серед населення, що проживає поблизу звалищ побутових відходів. У дорослого населення, що проживає у зоні впливу полігону, на 29\% підвищується імовірність розвитку захворювань нервової системи, на $16 \%$ - кістковом'язової системи, на 32\% шкіри $[9,11]$.

Але це лише одна сторона проблеми відходів, а інша 3 її складовими - транспортування та складування - не включені до розрахунків сумарного екологічного навантаження полігону ТПВ на довкілля.

Вихлопні гази містять близько 300 шкідливих сполук: важкі метали (свинець, радій, платину), канцерогенні (бенз(а)пірен, формальдегід, бензол), мутагенні і токсичні речовини (оксиди вуглецю, оксиди азоту, діоксид сірки, вуглеводні, сажу), які, потрапляючи до живого організму, призводять до розвитку незворотних змін через біоакумулюючий ефект [10]. Внаслідок дії на організм вихлопних газів виникають

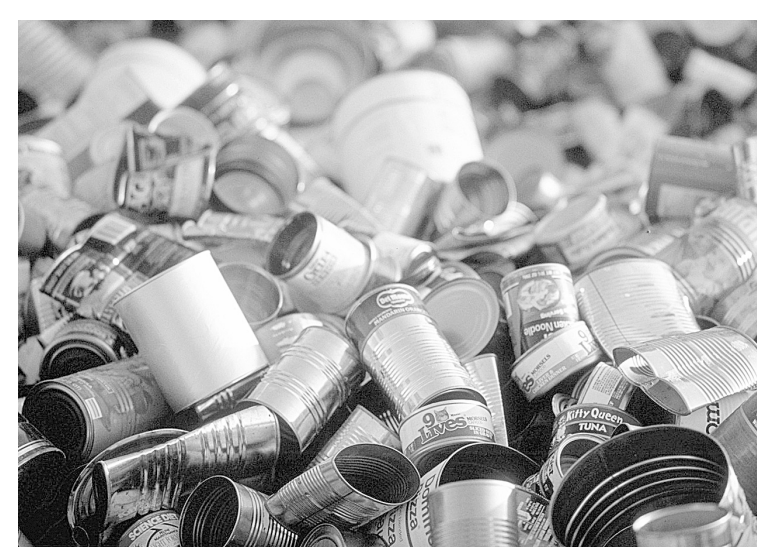

ГІГІЄНА ҐРУНТУ НАСЕЛЕНИХ МІСЦЬ

гострі та хронічні захворювання, серед яких найбільш поширеними $€$

口 боку дихальних шляхів: алергічне подразнення дихальних шляхів, бронхіти, астма, гайморит, емфізема легень, новоутворення;

$\square 3$ боку серцево-судинної системи: задишка, запаморочення, збільшення частоти нападів стенокардії, провокування розвитку інфаркту міокарда, утворення тромбів. Складники вихлопних газів викликають згущення крови і спричиняють тромбози, тромбоемболії, інфаркти міокарда. За рахунок впливу чадного газу на організм карбоксигемоглобін не може захопити кисень, що призводить до гіпоксії тканин (кисневе голодування). У зв'язку $з$ цим погіршується транспортування кисню до серцевого м'язу та створюєть- ся негативний вплив на систему кровообігу загалом;

$\square з$ боку нервової системи: загальна слабкість, апатія, депресія, дратівливість, порушення сну;

口 боку шкіри та слизових: алергічні дерматити, кон'юнктивіти [8, 11, 14].

Наведене вище свідчить про те, що процеси транспортування та захоронення ТПВ на полігонах мають значний вплив на довкілля та людину. Тому процеси транспортування і складування ТПВ на полігонах, коли довкілля забруднюється низкою токсичних, канцерогенних та мутагенних речовин 3 вихлопних газів автотранспорту, потребує дослідження та оцінки.

Мета. Проведення екологогігієнічної оцінки процесу захоронення ТПВ на полігонах на довкілля та людину.

Таблиця 1

Вплив етапів технологічного процесу захоронення відходів на атмосферне повітря залежно від виду процесу

\begin{tabular}{|c|c|c|c|c|c|}
\hline \multirow[b]{2}{*}{$\begin{array}{c}\text { Найменування } \\
\text { забруднюючого } \\
\text { фізичного чи } \\
\text { хімічного } \\
\text { чинника }\end{array}$} & \multirow{2}{*}{$\begin{array}{c}\text { Клас } \\
\text { небезпеки } \\
\text { / ГДК с.д. } \\
\text { в атмо- } \\
\text { сфері } \\
\text { населених } \\
\text { місць, } \\
\text { мг/м³ }\end{array}$} & \multicolumn{4}{|c|}{$\begin{array}{c}\text { Етап технологічного процесу } \\
\text { захоронення відходів }\end{array}$} \\
\hline & & $\begin{array}{c}\text { Заванта- } \\
\text { ження } \\
\text { авто- } \\
\text { мобіля, } \\
\text { мг/м³ }\end{array}$ & $\begin{array}{c}\text { Розван- } \\
\text { таження } \\
\text { авто- } \\
\text { мобіля, } \\
\text { мг/м³ }\end{array}$ & $\begin{array}{c}\text { Проїзд } \\
\text { терито- } \\
\text { рією } \\
\text { полігону, } \\
\text { мг/км }\end{array}$ & $\begin{array}{c}\text { Ущільнення } \\
\text { відходів, } \\
\text { мг/м }{ }^{3}\end{array}$ \\
\hline $\mathrm{CO}$ & $4 / 5$ & 2070 & 4276 & 62000 & $4724-11800$ \\
\hline $\mathrm{CO}_{2}$ & $4 / 3$ & 58,6 & 14,5 & 174 & $2480-14300$ \\
\hline $\mathrm{SO}_{2}$ & $3 / 0,05$ & 5,5 & 13,1 & 164 & 43,5 \\
\hline $\mathrm{C}_{\mathrm{x}} \mathrm{H}_{\mathrm{x}}$ & $3 / 0,071$ & 203,5 & 386 & 6300 & 220 \\
\hline $\mathrm{N}_{\mathrm{x}} \mathrm{O}_{\mathrm{x}}$ & $3 / 1,5$ & 76 & 162 & 2700 & $1860-17760$ \\
\hline Акролеїн & $2 / 0,03$ & 1,38 & 5,9 & 80 & 2,4 \\
\hline Формальдегід & $2 / 0,003$ & 1,38 & 5,9 & 80 & 2,4 \\
\hline Ангідрид сірчистий & $3 / 0,05$ & 1,38 & 5,9 & 80 & 2,4 \\
\hline Сажа & $3 / 0,05$ & 219,7 & 462 & 7510 & $510-1730$ \\
\hline Пил & $4 / 4$ & 7,6 & 18,3 & 280 & $100-3860$ \\
\hline Свинець & $1 / 0,0003$ & 16,9 & 36 & 530 & 23 \\
\hline Бенз(а)пірен & $1 / 1 \cdot 10^{-6}$ & $4,83 \cdot 10^{-4}$ & $7,93 \cdot 10^{-4}$ & $16,2 \cdot 10^{-3}$ & $4,83 \cdot 10^{-4}$ \\
\hline Шум & 80 дБА & 94 & 98 & 95 & 99 \\
\hline Вібрація & 80 дБА & $76-85$ & $86-89$ & $82-85$ & $85-90$ \\
\hline
\end{tabular}


обласний лабораторний центр МО3 України" для НДР № 0117 U004237 та результатів, отриманих іншими науковцями [3, 10], що дозволив виявити вплив техногенних факторів на довкілля.

Відбір проб атмосферного повітря здійснювали у поглиначі Ріхтера та Зайцева за допомогою електроаспіраторів "Тайфун Р-100", "АФА-ВП20" та "ЭА-1212". Аналіз проб проводили на фотоелектроколориметрі "КФК-2" та газовому хроматографі "Кристал $2000 \mathrm{M}^{\prime \prime}$

Розрахунки проведено згідно 3 "Методикою розрахунку викидів забруднюючих речовин та парникових газів у повітря від транспортних засобів" (Держкомстат України,

Таблиця 2

Вплив етапів процесу захоронення ТПВ на якість атмосферного повітря

\begin{tabular}{|c|c|c|c|c|}
\hline \multirow[b]{2}{*}{$\begin{array}{c}\text { Найменування } \\
\text { забруднювача } \\
\text { фізичного } \\
\text { чи хімічного }\end{array}$} & \multicolumn{4}{|c|}{ Етап технологічного процесу захоронення відходів } \\
\hline & $\begin{array}{c}\text { Зважування } \\
\text { автомобіля, } \\
\text { г/год. }\end{array}$ & \begin{tabular}{|c|} 
Розванта- \\
ження \\
автомобіля, \\
г/год. \\
\end{tabular} & $\begin{array}{c}\text { Проїзд } \\
\text { територією } \\
\text { полігону, } \\
\text { г/км }\end{array}$ & $\begin{array}{c}\text { Ущільнення } \\
\text { відходів, } \\
\text { г/год. }\end{array}$ \\
\hline $\mathrm{CO}$ & 60 & 124 & 62 & $137-342$ \\
\hline $\mathrm{CO}_{2}$ & 0,17 & 0,42 & 0,174 & $72-415$ \\
\hline $\mathrm{SO}_{2}$ & 0,16 & 0,38 & 0,164 & 1,26 \\
\hline $\mathrm{C}_{\mathrm{x}} \mathrm{H}_{\mathrm{x}}$ & 5,9 & 11,2 & 6,3 & 6,3 \\
\hline $\mathrm{N}_{\mathrm{x}} \mathrm{O}_{\mathrm{x}}$ & 2,2 & 4,7 & 2,7 & $54-515$ \\
\hline Акролеїн & 0,04 & 0,17 & 0,08 & 0,07 \\
\hline Формальдегід & 0,04 & 0,17 & 0,08 & 0,07 \\
\hline Ангідрид сірчистий & 0,04 & 0,17 & 0,08 & 0,17 \\
\hline Сажа & 6,37 & 13,4 & 7,51 & $14,7-50,17$ \\
\hline Пил & 0,22 & 0,53 & 0,28 & $3-112$ \\
\hline Свинець & 0,49 & 1,04 & 0,53 & 0,68 \\
\hline Бенз(а)пірен & $14410^{-6}$ & $23410^{-6}$ & $16,2410^{-6}$ & $\begin{array}{l}14 \times 10^{-4}- \\
24,4 \times 10^{-4}\end{array}$ \\
\hline Шум & 94 & 98 & 95 & 99 \\
\hline Вібрація & $76-85$ & $86-89$ & $82-85$ & $85-90$ \\
\hline
\end{tabular}

Зміна концентрації СO, $\mathrm{CO}_{2}, \mathrm{~N}_{\mathbf{x}} \mathrm{O}_{\mathrm{x}}$, пилу, що надходить у повітря від автотранспорту залежно від операції захоронення ТПВ

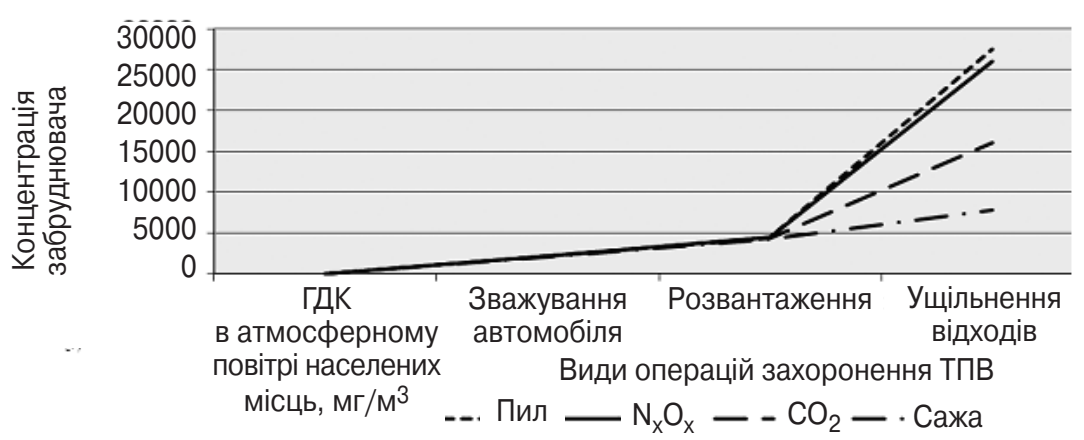

наказ № 452 від 13.11.2008р.) [15].

Результати досліджень та ïx обговорення. Згідно 3 даними комунального підприємства „Полігон ТПВ” в ІваноФранківській області [16] для захоронення побутових відходів на полігоні ТПВ площею 20,8 га використовується така техніка: бульдозер Т-170 - 2 одиниці; екскаватор ЕК-14 - 1 одиниця; автомобіль-самоскид КрАЗ - 1 одиниця. Щодня на полігон надходить близько 235 тонн відходів, які доставляються сміттєвозами різних марок - ГАЗ, КАМАЗ, МАЗ, Мерседес й іншими (вантажопідйомність сміттєвозів - від 5 до 10 тонн), а також самоскидами різних марок. Кількість автомобілів, які щодня доставляють відходи на полігон, становить 64-72 одиниці. В Україні до збору, вивезення та захоронення ТПВ залучено понад 176,5 тисяч одиниць автотранспорту.

Основними етапами технологічного процесу захоронення відходів є зважування автомобіля, проїзд територією полігону, розвантаження, ущільнення відходів.

Нами оцінено вплив кожної технологічної операції на атмосферу на прикладі комунального підприємства "Полігон ТПВ" в Івано-Франківській області (таблиці 1 та 2).

у середньому тривалість етапів процесу захоронення ТПВ для одного сміттєвоза становить

зважування - 2-3 хв.

р розвантаження - 3-5 хв.,

п проїзд територією полігону - у середньому 3000 м (до місця розвантаження і назад).

Ущільнення ТПВ на полігоні триває 8 год./добу.

У таблиці 2 наведено оцінку впливу етапів процесу захоронення ТПВ на довкілля залежно від тривалості процесу.

Тривалість етапів процесу захоронення ТПВ для усіх одиниць автотранспорту, що залучені до процесу захоронення, у середньому для 70 сміттєвозів та 4 одиниць техніки, яка використовується для ущільнення відходів, щодобово становить

$\square$ зважування - 6 год.,

р розвантаження - 12 год.

口 ущільнення - 32 год.,

проїзд територією полігону - у середньому 210 км (до 
ECOLOGICAL-AND- HYGIENIC ESTIMATION OF DOMESTIC WASTE TRANSPORTATION IMPACT ON THE LANDFILLS' AIR ENVIRONMENT

1 Malyshevska O., 2 Harkavyi S., 1 Myshchenko I. 1 Pohorilyi M., ${ }^{1}$ Tokar I., ${ }^{1}$ Hrechukch L. ${ }^{1}$ Ivano-Frankivsk National Medical University, 2 O.O. Bohomolets National Medical University, Kyiv, Ukraine

Objective. We carried out ecological-and-hygienic assessment of the impact of the process of burial disposal of solid household wasteonthe landfills on the environment and human.

Materials and methods. We analyzed the procedure of technological operations of burial disposal of household waste on an example of the municipal company "Polyhon TPV" in Ivano-Frankivsk region. The results were obtained as a result of field instrumental experiments by the specialists and with the help of the equipment of Ivano-Frankivsk Regional Laboratory Center of the Ministry of Health Care of Ukrainefor the scientificand-research work № 0117U004237. Analysis of air dust content was performed with the device "AFA-VP20"; determination of chemicals' concentrations in ambient air was done with the help of electric aspirator "ЭA1212", Richter's and Zaitsev's absorption cham- bers, photoelectric colorimeter "KFK-2", gas chromatograph "Crystal 2000 M". Calculations were conducted according to "The method of calculation of the emissions of the pollutants and greenhouse gases from vehicles into the atmosphere".

Results and discussion. Excess of MPCs and MPLs were indicated for all studied physical and chemical factors. In particular, excess of MPC for carcinogenic, mutagenic and highly toxic substances were for formaldehyde up to 1967 times, for lead - up to 120,000 times, for benz(o)pyrene - up to 793 times. Conclusions and prospects. The greatest emission of the pollutants in ambient air of the settlements is caused by the processes of unloading and compacting of waste; the maximum pollution is observed from the longest process, waste compacting. The main reason of waste excess is a physical deterioration of the vehicles, which transport solid waste to the landfill. The prospect direction of further research is the development and implementation of the technologies, reducing the amount of waste, exported for burial disposal and, in particular, polymers, the heaviest domestic refuse component.

Keywords: municipal hygiene, polymer waste, waste burial disposal, vehicle's emissions. місця розвантаження і назад).

Графічну ілюстрацію впливу етапів процесу захоронення ТПВ на повітряне середовище представлено на рисунках 1-5.

у таблиці 3 розраховано добове та річне техногенне навантаження на атмосферу, що створюються на етапах захоронення побутових відходів.

3 даних таблиць та рисунків випливає, що перевищення рівня ГДК і ГДР наявне за усіма фізичними та хімічними чинниками, що визначалися. Зокрема, мінімальним $€$ перевищення рівня ГДК за пилом 965 разів, а максимальним - перевищення для свинцю близько 120 тисяч разів.

Основною причиною такої ситуації $€$ фізичне зношення автопарку, який вивозить ТПВ на полігон. Згідно з отриманими даними по комунальному підприємству „Полігон ТВП” середній термін експлуатації сміттєвозів становить 17,8 років [16]. 3 них менше 5 років експлуатуються $12,7 \%$ автопарку; від 5 до 10 років 34,2\%; від 10 до 15 років 30,6\%; понад 15 років - 22,5\%.

Найбільшу емісію полютантів в атмосферу складають процеси розвантаження та ущільнення відходів. Максимально забруднює атмосферу найтриваліший процес захоронення ТПВ - ущільнення.

Висновки та перспективи подальших досліджень.
Відомо, що перевищення рівня ГДК і ГДР забруднення довкілля провокує виникнення гострих та хронічних захворювань різної форми та генезису у населення, що проживає у межах, які зазнають техногенного навантаження.

За даними аналізу експериментальних даних встановлено, що процес захоронення ТПВ має значний вплив на атмосферу полігону та прилеглих територій, і ним не можна знехтувати у зв'язку зі значним перевищенням рівня ГДК за усіма дослідженими речовинами.

Встановлено, що перевищення рівнів ГДК для канцерогенних, мутагенних та високотоксичних речовин становить для формальдегіду до 1967 разів, для свинцю - до 120 тисяч разів, для бенз(а)пірену - до 793 разів. кміна концентрації $\mathrm{SO}_{2}, \mathrm{C}_{\mathrm{x}} \mathrm{H}_{\mathrm{x}}$, сажі, що надходять у повітря від автотранспорту, залежно від операції захоронення ТПВ

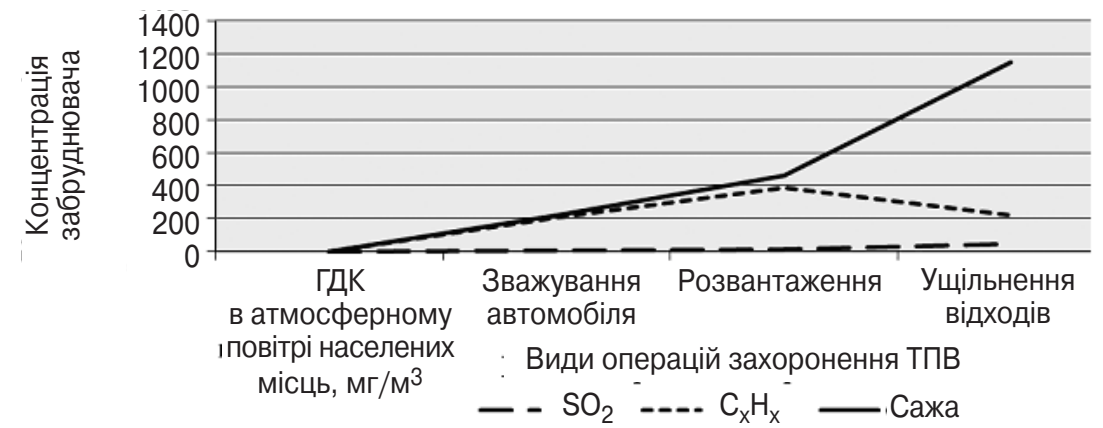

Ситуація, що склалася, вимагає прийняття рішень щодо її оптимізації. Оновити автопарк у повному обсязі спецтехнікою, рівень викиду якої задовольняє чинні гігієнічні норми, $€$ на даному етапі фінансово неперспективним. Модернізація вимагає значних капіталовкладень, що або викличе значне здороження процесу утилізації ТПВ, або перетворить малорентабельні комунальні підприємства захоронення на збиткові.

Окрім цього загостренню санітарно-гігієнічної ситуації сприяе розсіювання легких фракцій сміття за межі полігону, присутність значної кількості бездомних тварин та гризунів. Ускладнюють екологічну обстановку і значні об'єми фільтрату, що накопичується у понижених формах рельєфу полігону. Фільтрат активно

\section{Рисунок 2}

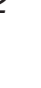


проникає у ґрунтові та підземні води і створює масштабні ареали забруднення, що поширюються у просторі та часі.

Основним напрямком подальших наукових досліджень $€$ розробка та впровадження технологій, які дозволяють зменшити обсяг відходів, що вивозиться на полігони і звалища.

ЛІТЕРАТУРА

1. Transport Energy and CO2: Moving Tovard Sustain-ability. 113-rd International TASI FORUM, 9 October 2009. 25 p.

2. Jaroszweski D., Hooper E., Chapman L. The impact of climate change on urban transport resilience in a changing world.

\section{Зміна концентрацій акролеїну, сірчистого ангідриду, формальдегіду, свинцю, що надходять у повітряне середовище від автотранспорту, залежно від операції захоронення ТПВ}

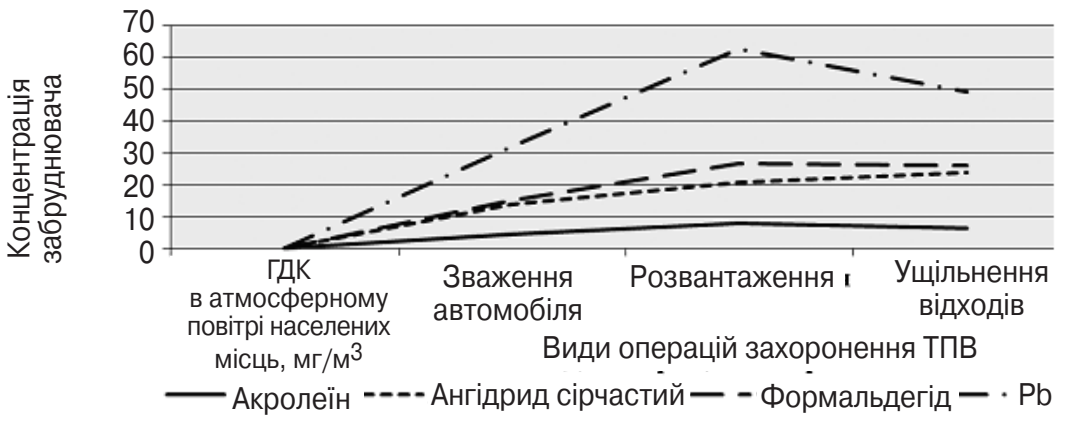

Рисунок 4

Зміна концентрації бенз(а)пірену, що надходить у повітря від автотранспорту, залежно від операції захоронення ТПВ
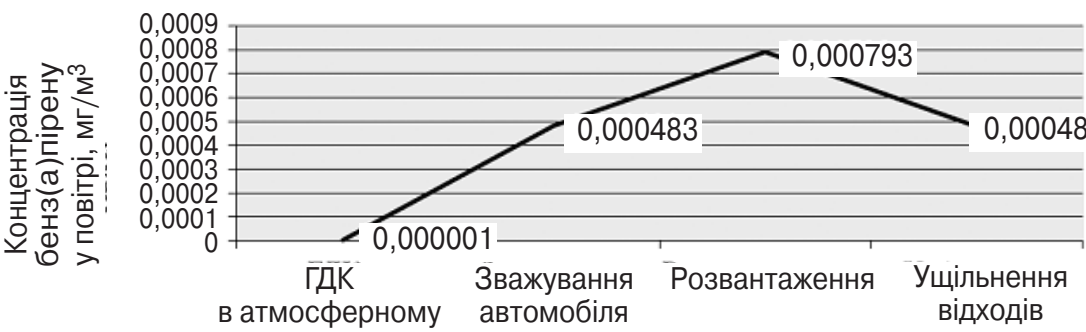
повітрі населених місць, мг $/ \mathrm{M}^{3}$

Види операцій процесу захоронення ТПВ

Рисунок 5

Зміна звукового та вібраційного навантаження на довкілля від автотранспорту залежно від операції захоронення ТПВ

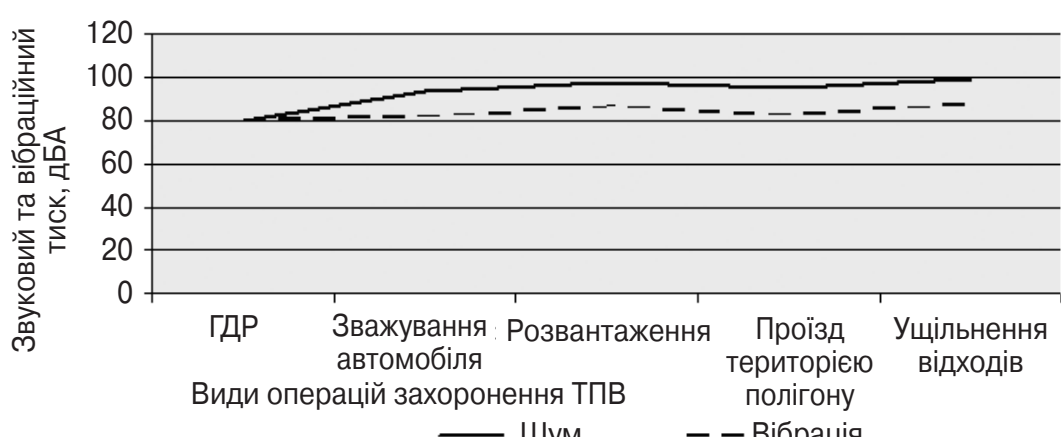

ukrstat.gov.ua/druk/publicat/kat u/publnav ser u.htm

6. Быстрых В.В. Комплексная оценка канцерогенной нагрузки селитебных территорий. Гигиена и санитария. 2002. № 5. С. 8-11.

7. Маймулов В.Г., Пацюк Н.А. Гигиеническая оценка влияния химического загрязнения окружающей среды мегаполиса на состояние здоровья детей. Гигиена и санитария. 2004. № 2. С. 31-33.

8. Новикова И.И., Оглезнев Г.А. Гигиенические проблемы окружающей среды и здоровья населения крупного промышленного центра. Гигиена и санитария. 2003. № 3. C. 66-68.

9. Kyle A.D., Wright C.C. Caldwell J.C. et al. Evaluating the health significance of hazardous air pollutants using monitoring data. Public Health Persp. 2001. № 1. P. 32-44.

10. McMichael A. The urban environment and health in a world of increasing globalization: Issues for deveioping countries. J. Bull. World Health Organ. 2000. № 9. P. 1117-1126.

11. Le Terte A., Medina S. Samoli E. et al. Short-term effects of particulate air pollution on cardiovascular diseases in eight European cities.

J. Epidemiol. and Community Health. 2002. № 10. P. 773-779.

12. Боев В.М., Куксанов В.Ф., Быстрых В.В. Химические канцерогены среды обитания и злокачественные новообразования. М. : Медицина, 2002. 343 c.

13. Мудрый И.В. Влияние химического загрязнения почвы на здоровье населения. Гигиена и санитария. 2008. № 4. С. 32-37.

14. Онищенко Г.Г., Новиков С.М., Рахманин Ю.А., Авалиани С.Л., Буштуева К.А. Основы оценки риска для здоровья населения при воздействии химических веществ, загрязняющих окружающую среду / под ред. Рахманина Ю.А., Онищенко Г.Г. Москва, 2002. 408 с.

15. Методика розрахунку викидів забруднюючих речовин та парникових газів у повітря від транспортних засобів. Затв. наказом Держкомстату України від 13.11.2008 р. № 452 зі змінами і доповнен- 
5. Dovkillia Ukrainyza 2016 rik:

нями. URL : http://ukrstat.org/ uk/metod_polog/metod_doc/20 08/452/metod.htm

16. Комунальне підприємство "Полігон ТПВ" в ІваноФранківській області. URL : http://www.namvk.if.ua/refdoc $/ 43864$

17. Гаркавий С.С. Гігієнічна оцінка динаміки міграції метилтрет-бутилового ефіру у ґрунті : автореф. дис. ... канд. мед. наук: 14.02.01 K., 2012. 22 c.

18. Argus MTBE Annual 2017 URL : http://www.argusmedia. com/ /media/files/pdfs/petche ms/argus-mtbe-annual2017.pdf?la=en.

REFERENCES

1. Transport Energy and CO2: Moving Tovard Sustainability. 113-rd International TASIFORUM, 9 October 2009. 25 p.

2. Jaroszweski D., Hooper E., and Chapman L. Progress in Physical Geography. 2014 ; 38 (4) : 448-463. doi:

$10.1177 / 0309133314538741$

3. Energy Technology

Perspectives. Scenarios and Strategies to 2050. Paris : International EnergyAgency, 2010 : $710 \mathrm{p}$.

4. Anisimov E.E. Molodoy uchenyi. $2014 ; 21: 71-72$ (in Russian)

statystychnyi zbirnyk [The

Environment of Ukraine for 2016: Statistical Collection]. State Statistics Committee of Ukraine. Kyiv, 2017 : 242 p. URL :http://www.ukrstat.gov.ua/druk /publicat/kat_u/publnav_ser_u.h tm (in Ukrainian).

6. Bystrykh V.V. Gigiena I sanitariya. $2002 ; 5: 8-11$

(in Russian).

7. Maimulov V.G. and

Patsiuk N.A. Gigiena / sanitariya. 2004 ; 2 : 31-33 (in Russian).

8. Novikova I.I. and Ogleznev G.A. Gigiena i sanitariya. 2003 ; 3 : 66-68 (in Russian). 9. Kyle A.D., Wright C.C.,

Caldwell J.C. et al. Public Health Persp. $2001 ; 1: 32-44$.

10. McMichael A. J. Bull. World Health Organ. 2000 ; 9 : 1117-1126.

11. LeTerte A., Medina S. Community Health. 2002 ; 10 : 773-779.

12. Boev V.M., Kuksanov V.F. and Bystryh V.V. Khimicheskie kantserogeny sredy obitaniia i zlokachestvennye novoobrazovaniia [Chemical Carcinogens of Habitat and Malignant

Neoplasms]. Moscow : Meditsina; 2002 : 343 p.

(in Russian).
Samoli E. et al. J. Epidemiol. and

Таблиця 3

Добове та річне забруднення атмосферного повітря від технологічних етапів процесу захоронення ТПВ

\begin{tabular}{|c|c|c|c|c|}
\hline \multirow[b]{2}{*}{$\begin{array}{c}\text { Найменування } \\
\text { забруднюючого } \\
\text { фізичного чи } \\
\text { хімічного чинника }\end{array}$} & \multicolumn{4}{|c|}{ Етап технологічного процесу захоронення відходів } \\
\hline & $\mid \begin{array}{c}\text { Зважування } \\
\text { автомобіля, } \\
\text { г/добу / } \\
\text { кГ/рік }\end{array}$ & \begin{tabular}{|c|} 
Розванта- \\
ження \\
автомобіля, \\
г/добу / \\
кг/рік
\end{tabular} & \begin{tabular}{|c|} 
Проїзд \\
територією \\
полігону, \\
г/добу / \\
кг/рік
\end{tabular} & $\begin{array}{l}\text { Ущільнення } \\
\text { відходів, } \\
\text { г/добу / } \\
\text { кг/рік }\end{array}$ \\
\hline $\mathrm{CO}$ & & $1513 / 552,2$ & $13400 / 4$ & \\
\hline $\mathrm{CO}_{2}$ & $1,02 / 0,372$ & $5,12 / 1,87$ & $37,59 / 13,72$ & 1328 \\
\hline $\mathrm{SO}_{2}$ & $96 / 0,35$ & $0,47 / 1,7$ & $35,42 / 12,93$ & $40,33 / 14,72$ \\
\hline $\mathrm{C}_{\mathrm{x}} \mathrm{H}_{\mathrm{x}}$ & $35,4 / 12,92$ & $136,63 / 49,87$ & $1360 / 496,7$ & $201,6 / 73,58$ \\
\hline $\mathrm{N}_{\mathrm{x}} \mathrm{O}_{\mathrm{x}}$ & $3,2 / 4,82$ & $57,34 / 20,93$ & $580 / 212,9$ & $16480 / 6015$ \\
\hline Акролеїн & $0,238 / 0,087$ & $1,96 / 0,761$ & $17,26 / 6,31$ & $2,24 / 0,818$ \\
\hline Формальдегід & $0,238 / 0,087$ & $1,96 / 0,761$ & $17,26 / 6,31$ & $2,24 / 0,818$ \\
\hline Ангідрид сірчистий & $0,238 / 0,087$ & $1,96 / 0,761$ & $17,26 / 6,31$ & $2,24 / 0,818$ \\
\hline Сажа & $38,22 / 3,95$ & $1,96 / 59,67$ & $1620 / 592,1$ & $1600 / 586$ \\
\hline Пил & $1,315 / 0,48$ & $6,47 / 2,36$ & $60,49 / 22,08$ & $3580 / 1308$ \\
\hline Свинець & $2,94 / 1,073$ & $12,69 / 4,63$ & $114,5 / 41,79$ & $21,76 / 7,94$ \\
\hline Бенз(а)пірен & $\begin{array}{l}8,8 \times 10^{-5} / \\
3,06 \times 10^{-5}\end{array}$ & $\begin{array}{l}2,8 \times 10^{-4} / \\
1,024 \times 10^{-4}\end{array}$ & $\begin{array}{l}3,5 \times 10^{-3} / \\
1,28 \times 10^{-3}\end{array}$ & $\begin{array}{c}0,0448 / \\
0,0164\end{array}$ \\
\hline Шум & 94 & 98 & 95 & 99 \\
\hline Вібрація & $76-85$ & $86-89$ & $82-85$ & $85-90$ \\
\hline
\end{tabular}

13. Mudryi I.V. Gigiena i sanitariya. $2008 ; 4: 32-37$ (in Russian).

14. Onishchenko G.G. Novikov S.M., Rakhmanin Yu.A., Avaliani S.L. and Bushtueva K.A. Osnovy otsenki riska dlia zdorovia naseleniya pri vozdeistvii khimicheskikh veshchestv, zagriazniaiushchikh okruzhaiushchuyu sredu [Basics of the Assessment of the Population's Health Risk under Effect of Chemicals Contaminating the Environment]. Moscow; 2002 : 408. (in Russian).

15. Metodyka rozrakhunku vykydiv zabrudniuiuchykh rechovyn ta parnykovykh haziv u povitria vid transportnykh zasobiv. Nakaz Derzhavnoho komitetu statystyky Ukrainy vid

13.11.2008 № 452 zi zminamy i dopovnenniamy [Methodology for the Calculation of the Emissions of Pollutants and Greenhouse Gases from the Vehicles in the Air] : Order of the State Statistics Committee of Ukraine, 13.11.2008 № 452 with Amendments and Supplements. URL : http://ukrstat.org/uk/ metod_polog/metod_doc/2008/ 452/metod.htm (in Ukrainian).

16. Komunalne pidpryiemstvo "Polihon TPV" v IvanoFrankivskyi oblasti ["Poligon waste" Municipal Enterprise in Ivano-Frankivsk oblast]. URL : http://www. namvk.if.ua/refdoc/43864 (in Ukrainian).

17. Harkavyi S.S. Hihiienichna otsinka dynamiky mihratsii metyltretbutylovoho efiru v grunti [Hygienic Estimation of the Migration of Methyltertiarybutyl Ether in Soil : Abstract of the Dissertation to the Degree of the Candidate of Medical Sciences]. Kyiv; 2012 : 22 p. (in Ukrainian).

18. Argus MTBE Annual 2017. URL : http://www. argusmedia. com/ /media/files/pdfs/petche ms/argus-mtbe-annual2017.pdf?la=en

Надійшло до редакції 10.02.2018 